\title{
Segment selection by relationship strength
}

Citation for published version (APA):

Schijns, J. M. C., \& Odekerken-Schröder, G. J. (1995). Segment selection by relationship strength. METEOR, Maastricht University School of Business and Economics. METEOR Research Memorandum No. 038 https://doi.org/10.26481/umamet.1995038

Document status and date:

Published: 01/01/1995

DOI:

10.26481/umamet.1995038

Document Version:

Publisher's PDF, also known as Version of record

\section{Please check the document version of this publication:}

- A submitted manuscript is the version of the article upon submission and before peer-review. There can be important differences between the submitted version and the official published version of record.

People interested in the research are advised to contact the author for the final version of the publication, or visit the DOI to the publisher's website.

- The final author version and the galley proof are versions of the publication after peer review.

- The final published version features the final layout of the paper including the volume, issue and page numbers.

Link to publication

\footnotetext{
General rights rights.

- You may freely distribute the URL identifying the publication in the public portal. please follow below link for the End User Agreement:

www.umlib.nl/taverne-license

Take down policy

If you believe that this document breaches copyright please contact us at:

repository@maastrichtuniversity.nl

providing details and we will investigate your claim.
}

Copyright and moral rights for the publications made accessible in the public portal are retained by the authors and/or other copyright owners and it is a condition of accessing publications that users recognise and abide by the legal requirements associated with these

- Users may download and print one copy of any publication from the public portal for the purpose of private study or research.

- You may not further distribute the material or use it for any profit-making activity or commercial gain

If the publication is distributed under the terms of Article $25 \mathrm{fa}$ of the Dutch Copyright Act, indicated by the "Taverne" license above, 


\title{
Segment Selection by Relationship Strength
}

\author{
Jos M.C. Schijns \\ and \\ Gaby J. Schröder
}

(C) 1995 University of Limburg | Maastricht

All rights reserved. No part of this publication may be reproduced or utilized in any form or by any means, electronic or mechanical, including photocopying, recording or by any information storage and retrieval system, without prior written permission from the copyright owner, or, as the case may be, the publishers, beyond the exceptions provided for in the Copyright Law. 


\title{
Segment Selection by Relationship Strength
}

\author{
Jos M.C. Schijns \\ and \\ Gaby J. Schröder
}

Relationship management is becoming more important in direct marketing, since the emphasis in marketing is moving from a transaction focus to a relationship focus (e.g. Barlow, 1992; Cannon \& Sheth, 1994; Webster, 1992). However, problems arise when measuring the strength of relationships between a company and its customers. Whereas relationship strength could be used as a segmentation variable.

In measuring relationship strength, some studies concentrate on one indicator at a time, e.g. the length of the relationship. Other studies use a combination of indicators, like the $R / F / M$ formula in the direct marketing world (e.g. Baier, 1985). These indicators however, measure customer quality instead of relationship quality (which is used as a synonym of strength here) (Hoekstra, 1993; Wilson, 1990).

The present study intended to measure relationship strength, of different consumer groups (i.c. current, former and potential members of a marketing club) with the same producer, through a relationship audit (Wilson, 1989). This audit depends on customer attitudes towards the relationships. These attitudes can not be derived from a database in which mainly behavioral data are kept.

The results of the audit are related to behavioral data from the same study (that could be registrated in a database). Similarities between the two standards imply that the audit could be substituted by data from a (direct marketing) database.

The relationship audit as well as the behavioral data show striking differences between different consumer groups. So these groups can be approached by an appropriate (direct marketing) strategy, based on differences in relationship strength.

(C) 1995 University of Limburg | Maastricht

All rights reserved. No part of this publication may be reproduced or utilized in any form or by any means, electronic or mechanical, including photocopying, recording or by any information storage and retrieval system, without prior written permission from the copyright owner, or, as the case may be, the publishers, beyond the exceptions provided for in the Copyright Law. 


\title{
Segment Selection by Relationship Strength
}

\author{
Jos M.C. Schijns ${ }^{1}$ \\ and \\ Gaby J. Schröder ${ }^{2}$
}

\begin{abstract}
Relationship management is becoming more important, also in direct marketing. Measuring the strength of relationships is relevant, since relationship strength can be used as a segmentation variable. However, in measuring relationship strength, mostly one or more behavioral indicators are used (e.g. the R/F/M-formula). So, these indicators measure customer quality instead of relationship quality, which is mainly determined by customer perceptions. This paper shows some preliminary results of a relationship audit, which depends on customer attitudes towards the relationship.
\end{abstract}

1 Jos M.C. Schijns is an assistant professor of marketing at the University of Limburg, Faculty of Economics and Business Administration, Management Sciences, P.O. Box 616, 6200 MD Maastricht, The Netherlands, Telephone: +31-43-3883855, Telefax: +31-43-3210265, E-mail:

J.Schijns@mw.rulimburg.nl

2 Gaby J. Schröder is an assistant professor at the University of Limburg, Telephone: +31-43-3883618, Telefax: +31-43-3210265, E-mail: G.Schröder@mw.rulimburg.nl 


\section{INTRODUCTION}

Building, maintaining, and enhancing relationships with customers is becoming more important since the emphasis in marketing is moving from a transaction focus to a relationship focus (e.g. Barlow 1992; Berry 1983: 25; Cannon and Sheth 1994; Christopher et al. 1991: 8; Kotler 1994: 47; MSI 1991; Palmer 1994; Parvatiyar and Sheth 1994; Webster 1992: 7), also in direct marketing (Bauer and Miglautsch 1992). However, problems arise when measuring the (differences in) strength of relationships between a focal firm and its different groups of customers. In measuring the strength of relationships between producer and customers, mostly behavioral indicators (e.g. length of the relationship, recency, frequency or monetary value) for that strength are used.

Purpose of this study was to measure relationship strength not only by individual, behavioral indicators, but also by means of a relationship audit like Wilson (1990) proposed for industrial buyer-seller relationships. In order to find out whether behavioral data, captured in a (direct marketing) database, are sufficient to measure relationship strength, the results of this relationship audit, which focuses on attitudes, were compared to a number of individual, behavioral indicators used.

Although the customer audit by Wilson (1990) was designed for industrial markets, our empirical study has been conducted in and adapted to a consumer marketing environment.

First some theoretical viewpoints of measuring relationship strength will be presented and discussed. Attention will be paid to indicators and codes for measuring the strength and to the difference between customer importance and relationship strength, on which the customerrelationship matrix is based. The final part of the first section describes the relationship audit used in the present study. In the second section the research design will be clarified. In this section topics like research objectives, methodology, data collection and research questions and hypotheses will be discussed. The third section shows some preliminary results with respect to response, relationship audit, behavioral and mental data, the customer-relationship matrix and the testing of hypotheses. Finally a discussion and conclusion will be presented.

\section{THEORY OF MEASURING RELATIONSHIP STRENGTH}




\section{Indicators for measuring relationship strength}

In most studies, when measuring relationship strength, one indicator at a time is used. Since a behavioral and a mental dimension can be distinguished in a relationship (Peelen 1991; Poiesz and Van Raaij 1993; Storm 1991), the individual indicator can be behavioral (descriptive) or mental (attitudinal) in its nature.

From the behavioral point of view indicators like length of the relationship, recency, frequency, monetary value and regularity are used most often to get an idea of relationship strength. Another behavioral indicator could be whether the customer simultaneously uses also competing companies, or only uses company X (Liljander and Strandvik 1994: 15).

For example, "Relationship length is usually considered as some kind of strength" (Liljander and Strandvik 1994: 14). Accordingly, Peelen et al. (1989: 10) state that a higher frequency suggests a stronger relationship, and that, with respect to regularity, smaller variances indicate a stronger relationship, because of the increased predictability of future behavior.

From the mental viewpoint a variable like satisfaction, attractivity, perceived switching costs, trust, involvement or long-term expectations has been used as an indicator for relationship strength.

\section{Codes for measuring relationship strength}

Although usually, one (behavioral) indicator (e.g. relationship length) is considered as some kind of relationship strength, in direct marketing context 'codes' are used as well (Hoekstra 1994: 21). A code is a combination of indicators, like the Recency/Frequency/Monetary value (RFM) formula for characterizing transactions. Mostly, these codes are of the behavioral type, since they can be captured in a database easily.

\section{Customer importance and relationship strength}

However, the strength of a relationship can be derived only partly from behavioral variables, since they only give an indication (Hoekstra 1993: 81).

Moreover, indicators and codes in fact say more about customer importance and value of the account to the company, than about relationship strength. However, in practice, an important and valuable customer is used as a synonym of a strong relationship (Hoekstra 1993: 81; 1994: 20).

A good customer is a customer who contributes a relatively large share to the return of the 
organization within a certain period, which in particular can be derived from the behavioral variables in the database.

The quality or strength of a relationship, on the other hand, is determined by customer perceptions. So, a strong relationship is a relationship that is perceived as such by the customer. This depends on the attitude of the customer towards the relationship, which can not be derived from the database. Mainly primary research is required to find out how customers perceive their relationship with the supplier (Hoekstra 1993; 1994).

\section{The customer-relationship matrix}

Based on the difference between customer importance and relationship strength Wilson (1990: 13) and Hoekstra (1993: 82; 1994: 20) present a customer-relationship matrix (see table 1).

Table 1: $\quad$ The customer-relationship matrix

\begin{tabular}{|c|c|c|c|}
\hline & & \multicolumn{2}{|c|}{ Quality of customer } \\
\hline & & High & Low \\
\hline \multirow[t]{2}{*}{ Relationship } & Strong & 1 & 2 \\
\hline & Weak & 3 & 4 \\
\hline
\end{tabular}

Adapted from: Hoekstra (1994)

Cell number 1 contains the good (best) customers with a strong relationship or a high ability to develop one. These customers both drive your economics and gauge customer loyalty. Cell number 2 consists of those customers with a strong relationship who do not contribute to a large extent to the return of the company. The customers in cell number $\mathbf{3}$ should be bond to the organization more, while those in cell number $\mathbf{4}$ should be monitored without spending a lot of marketingdollars, since they can turn into a good customer, develop a strong relationship or both.

\section{The relationship audit}

So, a good customer differs from a strong relationship (Hoekstra 1993: 82). For that reason Wilson (1990) developed a relationship audit in order to measure the strength of relationships in an industrial market environment. After auditing all of the high value and important customers and potential customers (which can be done by the behavioral variables in the database), this relationship audit should classify these customers further according to their 
ability to develop a strong relationship with them, depending on the attitude of the customer towards the relationship.

The sum of the individual itemscores of this audit gives an approximation of the strength of a relationship, while the response to the individual questions provides an estimation of areas of strengths and weaknesses. "Based upon the results of the audit programs can be created to build upon strengths and correct weaknesses. The audit helps define the quality of relationships with key customers and makes explicit the actions necessary to build strong relationships" (Wilson 1990: 10).

In order to find out whether a relationship audit can be applied to a consumer marketing environment also, in order to measure relationship strength and fill out the customerrelationship matrix, the present study was conducted.

\section{RESEARCH DESIGN}

\section{Research objectives}

The first objective of this study was to measure the strength of relationships between consumers and a producer of a fast moving consumer good (in this case beer), by means of a relationship audit. There were three reasons in favor of the relationship audit:

a) The producer did not have a database with behavioral data that could be used as indicators for relationship strength;

b) As already mentioned, the strength of a relationship can be derived only partly from this kind of behavioral variables, since they only give an indication (Hoekstra 1993: 81) and do not measure relationship strength itself;

c) This kind of behavioral variables in fact say more about customer importance and value, than about relationship strength, which depends on the attitude of the customer towards the relationship.

The second objective of this study was to find out whether the audit is able to show differences in relationship strength between different groups of consumers.

The third objective was to compare the results of the audit with behavioral data, that could be captured in a (direct marketing) database, in order to find out whether these data could be used as a reliable indicator for relationship strength in the future. 


\section{Methodology}

The study has been conducted in a marketing club context in the consumer market of fast moving consumer goods. In this setting enduring relationships appeared important, namely the relationship between consumers and producer.

The producer concerned, concentrates his activities on the catering industry, on distributors and on the consumer market. The first two market segments are being approached satisfactory by means of specific strategies and instruments. The approach of the consumer market left a lot to be desired in the past. The marketing club was created as an innovative way of approaching consumers. An assumption underlying this decision is the opportunity to create relationships between the producer and consumers. Therefore, this situation provided an excellent environment to measure the assumed relationship strength by means of the relationship audit.

A mail survey was conducted to determine the employability of the relationship audit for assessing relationship strength. Based on an extensive literature study, a questionnaire was compiled, consisting of a number of questions that address the constructs of satisfaction, trust, switching costs, involvement and attractivity, which research has found to be critical in the development of relationships (e.g.: Morgan and Hunt 1994; Wilson 1990). Each construct was measured by one or more items/questions.

The questionnaire was made up of two sections. The first section was designed, first, to gather behavioral data (as the producer did not have a database with behavioral data) and, second, to measure the constructs of the relationship audit in order to assess the relationship strength. The second section was meant to gather socio-demographic data.

Within the first section several behavioral indicators of relationship strength have been measured, e.g.: length, recency, frequency, monetary value, and regularity. The relationship audit was made up of the constructs: satisfaction, trust, perceived switching costs, involvement and attractivity as mentioned previously.

Most of the items were measured by five-point Likert-type scales or by means of a Semantic Differential. The remaining items have been transformed into five answer categories afterwards.

\section{Data collection}

Before drawing a sample it is necessary to define the population about which inferences have 
to be made. The population of the present study was divided into three subpopulations:

- $\quad$ current members of a marketing club (total approximately 4500);

- former members of a marketing club (total approximately 1200);

- $\quad$ potential members of a marketing club (approximately 700).

If only current customers of the firm would have been selected, their answers would have been heavily biased towards (satisfaction with) the relationship. However, according to Liljander and Strandvik (1994: 21), in most studies only current members have been investigated. Two other groups would probably give another answer when evaluating the firm. According to Liljander and Strandvik (1994: 21) these groups are:

- customers that have ended their relationship with the firm (e.g. former members in the present study), and

- customers that never have bought from the provider but are in the market (e.g. potential members in the present study).

As we are not only interested in whether the relationship audit is a useful instrument to measure relationship strength in consumer markets, but also whether this audit is able to show differences in that strength between different groups of consumers, we investigated all three of the above mentioned groups: current members, former members and potential members.

The current and former members were approached by using the database of the company. A database which holds records of names, addresses, and ZIP codes. The potential members were more difficult to plot. It was decided to take into consideration customers who showed interest in the company in the past. A database with names, addresses, and ZIP codes of participants in a sales promotion activity has been used as a sample frame for the third subpopulation.

A systematic sample of approximately 600 addresses per database was drawn in which every $k^{\text {th }}$ element in each database was designated for inclusion in the sample after a random start.

So, in total approximately 1800 questionnaires have been sent by mail. Respondents were given four weeks to return the questionnaire.

\section{Research questions and hypotheses}

The research questions can be derived from our research objectives. First of all: does the relationship audit show differences in the strength of the relationships between three groups of consumers of beer (current members, former members and potential members of a marketing club set up by the producer) and the producer of the beer? 
Second, if there are differences in relationship strength, based on the relationship audit, are there differences in the behavioral data as well? The answers to these two questions will provide an answer to the third question: what data should be captured in a (direct marketing) database in order to measure relationship strength continuously?

Related to the first research question, the following hypotheses have been tested:

H1: Current members of the marketing club have a relationship which is stronger than the relationship former members and potential members have with the same producer.

H2: Former members of the marketing club have a relationship which is stronger than the relationship potential members have with the same producer.

Related to the second research question,

H3: If the relationship audit shows a difference in relationship strength, then there will be differences in the behavioral data as well.

Related to the last research question,

H4: The database should contain behavioral as well as attitudinal data, in order to measure relationship strength continuously. 


\section{RESULTS}

\section{Response}

The response amounted to 718 out of 1842 questionnaires (39\%). The results of further calculations of the response are shown in Table 2.

Table 2: $\quad$ Response figures

\begin{tabular}{||l|l|l|l|l||}
\hline GROUP & \# questionn. & \# response & $\begin{array}{l}\text { response in \% } \\
\text { of total }\end{array}$ & $\begin{array}{l}\text { response in \% } \\
\text { of group }\end{array}$ \\
\hline $\begin{array}{l}\text { current } \\
\text { members }\end{array}$ & 586 & 430 & 59.9 & 73.4 \\
\hline $\begin{array}{l}\text { former } \\
\text { members }\end{array}$ & 616 & 97 & 13.5 & 15.7 \\
\hline $\begin{array}{l}\text { potential } \\
\text { members }\end{array}$ & 640 & 184 & 25.6 & 28.8 \\
\hline $\begin{array}{l}\text { useless } \\
\text { total }\end{array}$ & - & 7 & 1 & - \\
\hline \hline
\end{tabular}

\section{Relationship audit}

Table 3: $\quad$ Mean and response $(\mathrm{N})$ regarding the relationship audit/strength

\begin{tabular}{||l|l|l|l|l||}
\hline $\begin{array}{l}\text { RELATION- } \\
\text { SHIP } \\
\text { audit/strength }\end{array}$ & $\begin{array}{l}\text { current } \\
\text { members }\end{array}$ & $\begin{array}{l}\text { former } \\
\text { members }\end{array}$ & $\begin{array}{l}\text { potential } \\
\text { members }\end{array}$ & total \\
\hline current & $55.6(162)$ & $\mathrm{p}=0.0004$ & $\mathrm{p}=0.0247$ & $\mathrm{p}=0.2676$ \\
\hline former & & $49.7(34)$ & $52.3(44)$ & \\
\hline potential & & & & $\begin{array}{l}54.1(240) \\
\mathrm{p}=0.0007\end{array}$ \\
\hline total & & & & \\
\hline
\end{tabular}

The values for relationship strength measured by the audit, ranged from 29 to 84 . Overall, from table 3 it can be concluded that there is a significant difference in relationship strength between current members, former members and potential members, based on the relationship 
audit. The current members differ significantly from former and potential members. Former members and potential members do not differ significantly, although the average relationship strength for potential members is higher than that of former members.

\section{Behavioral data}

Besides the relationship audit, a number of behavioral variables have been measured as an indicator for relationship strength, namely frequency, length, monetary value, recency and regularity.

Table 4 shows the results of the measurements related to the variable recency. All variables have been measured on a scale ranging from 1 to 5 , in which 1 points into the direction of a weak relationship and 5 into the direction of a strong relationship. Table 4 shows that current and potential members had recent contacts with the company or bought products recently. This recency variable is significantly weaker for former members of the marketingclub.

Table 4: $\quad$ Mean and response $(\mathrm{N})$ regarding recency

\begin{tabular}{||l|l|l|l|l||}
\hline RECENCY & $\begin{array}{l}\text { current } \\
\text { members }\end{array}$ & $\begin{array}{l}\text { former } \\
\text { members }\end{array}$ & $\begin{array}{l}\text { potential } \\
\text { members }\end{array}$ & total \\
\hline current & $4.5(430)$ & $\mathrm{p}=0.0002$ & $\mathrm{p}=0.9090$ & \\
\hline former & & $4.0(97)$ & $\mathrm{p}=0.0024$ & \\
\hline potential & & & $4.5(184)$ & \\
\hline total & & & & $\begin{array}{l}4.4(711) \\
\mathrm{p}=0.0005\end{array}$ \\
\hline
\end{tabular}

The tables presenting the results of the other behavioral data have been included in appendix 1 . Analyses of the variable regularity (table 6, appendix 1) show that current members score highest and former members lowest. The differences between current and former members is statistically significant as well as the difference between former and potential members. The results of the frequency (table 7 , appendix 1) variable are slightly different although the differences between current and former members and between former and potential members are statistically significant again. Regarding this variable however, the scores for current members and potential members are exactly the same, indicating frequent interactions. The results of the variable monetary value (table 8 , appendix 1) show significant differences 
between current and former members and between current and potential members. Former and potential members score exactly the same on this variable. Finally the analyses of the variable length (table 5, appendix 1) show a completely different picture. Current and former members expressed the longest relationship with the company, whereas potential members expressed a shorter relationship. Thus, there's no significant difference between current and former members and there are significant differences between current and potential members and between former and potential members.

From tables 4-8 (tables 5-8 can be found in appendix 1) it can be concluded that there are significant differences between current members, former members and potential members, with respect to all the behavioral variables measured, i.c. length of the relationship, recency, regularity, frequency and monetary value.

Table 9 summarizes the means of both, relationship strength based on the relationship audit and the behavioral variables.

Table 9: $\quad$ Means of both, relationship audit and behavioral variables

\begin{tabular}{||l|l|l|l|l|l|l||}
\hline $\begin{array}{l}\text { VARI- } \\
\text { ABLE }\end{array}$ & current members & & former members & & potential members & total \\
\hline $\begin{array}{l}\text { rel. audit } \\
\text { length }\end{array}$ & 55.6 & $>$ & 49.7 & $<$ & 52.3 & 54.1 \\
\hline $\begin{array}{l}\text { recency } \\
\text { regularity }\end{array}$ & 4.5 & $<$ & 4.6 & $>$ & 4.0 & 4.4 \\
\hline $\begin{array}{l}\text { frequency } \\
\text { mon. value }\end{array}$ & 3.7 & $>$ & 4.0 & $<$ & 4.5 & 4.4 \\
\hline \hline
\end{tabular}

All behavioral variables, with the exception of length, point into the same direction as relationship strength/audit.

\section{Mental data}

Table 10 summarizes the means of the mental variables.

Table 10: $\quad$ Means of mental variables 


\begin{tabular}{||l|l|l|l|l|l|l||}
\hline $\begin{array}{l}\text { VARI- } \\
\text { ABLE }\end{array}$ & current members & & former members & & potential members & total \\
\hline attractivity & 4.1 & $>$ & 3.6 & $<$ & 4.0 & 4.0 \\
\hline $\begin{array}{l}\text { involve- } \\
\text { ment }\end{array}$ & 4.3 & $>$ & 3.8 & $<$ & 4.1 & 3.0 \\
\hline \begin{tabular}{l} 
satisfaction \\
\hline $\begin{array}{l}\text { switch } \\
\text { costs }\end{array}$
\end{tabular} & 3.2 & $>$ & 2.4 & $<$ & 2.6 & 4.2 \\
\hline $\begin{array}{l}\text { trust } \\
\text { trust }\end{array}$ & $>$ & 1.5 & $=$ & 1.5 & 1.6 \\
\hline
\end{tabular}

Table 10 shows that the scores of current members on the mental variables indicate strong positive feelings towards the company. Potential members express slightly less strong positive feelings towards the company, whereas scores of former members are weakest.

\section{Customer-relationship matrix}

In the previous sections behavioral and mental variables have been discussed separately. Now the customer-relationship matrix will be clarified, showing similarities and differences between relationship strength and customer quality. The legend clarifying table 11 is presented on the next page.

Table 11: The customer-relationship matrix

\begin{tabular}{|c|c|c|c|c|}
\hline & & \multicolumn{3}{|c|}{$\begin{array}{l}\text { Quality of customer measured by monetary } \\
\qquad \text { value } \\
\text { observed frequency (expected frequency) }\end{array}$} \\
\hline & & Low & Medium & High \\
\hline \multirow{3}{*}{$\begin{array}{l}\text { Relationship } \\
\text { measured by audit } \\
\text { observed frequency } \\
\text { (expected frequency) }\end{array}$} & Weak & $32(21,2)$ & $8(14,7)$ & $1(5,1)$ \\
\hline & Medium & $81(83,2)$ & $65(57,7)$ & $15(20,1)$ \\
\hline & Strong & $11(19,6)$ & $13(13,6)$ & $14(4,8)$ \\
\hline
\end{tabular}




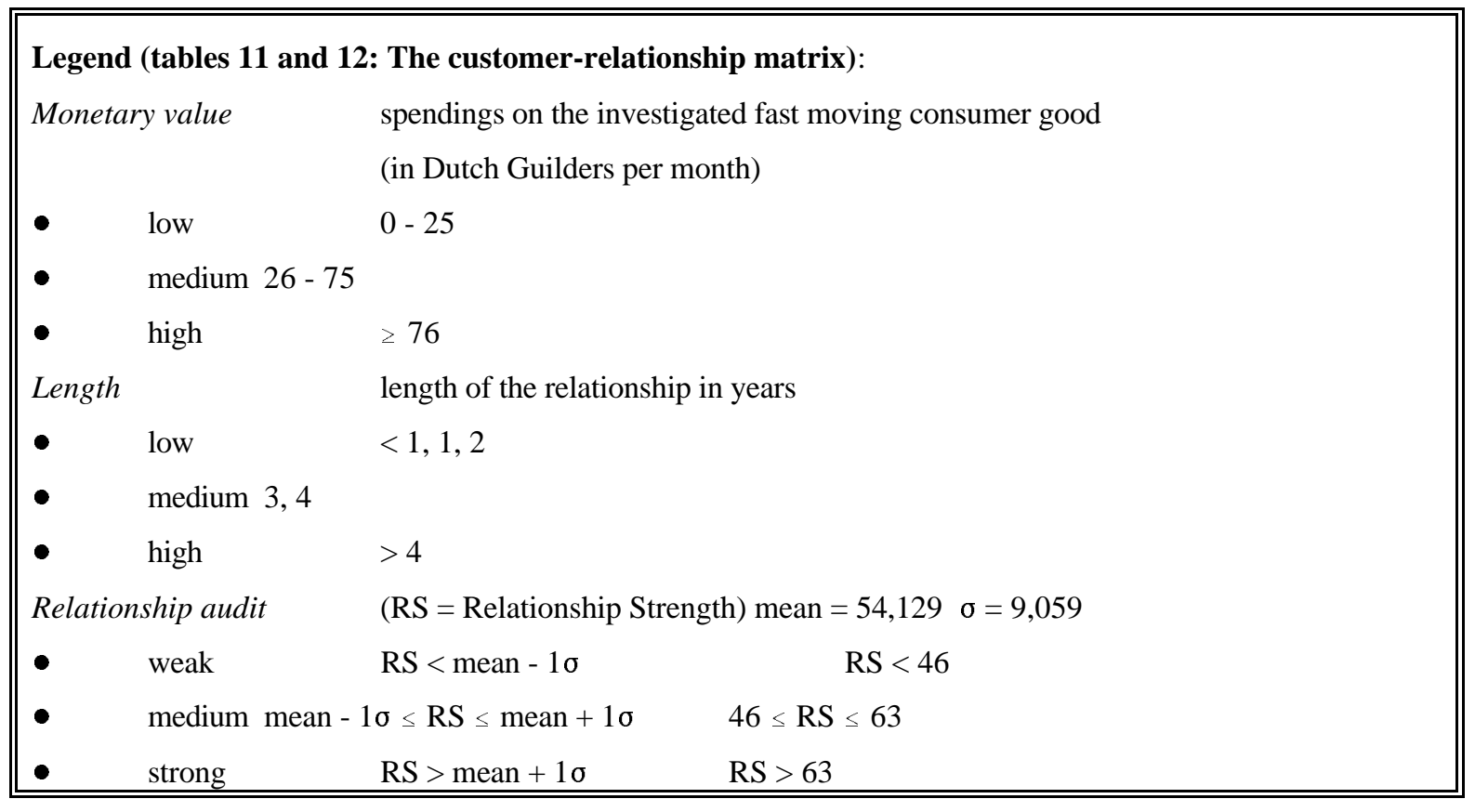

A chi-square analysis (significance level of 99.99\%) of this crosstable shows a statistically significant relationship between relationship strength and customer quality expressed by means of the variable 'monetary value'. This implies that the behavioral variable monetary value offers the same information as the mental variables included in the relationship audit.

Table 12: $\quad$ The customer-relationship matrix

\begin{tabular}{|c|c|c|c|c|}
\hline & & \multicolumn{3}{|c|}{$\begin{array}{l}\text { Quality of customer measured by length } \\
\text { observed frequency (expected frequency) }\end{array}$} \\
\hline & & Low & Medium & High \\
\hline \multirow{3}{*}{$\begin{array}{l}\text { Relationship } \\
\text { measured by audit } \\
\text { observed frequency } \\
\text { (expected frequency) }\end{array}$} & Weak & $2(2,7)$ & $8(5,6)$ & $31(32,6)$ \\
\hline & Medium & $13(10,7)$ & $22(22,1)$ & $126(128,1)$ \\
\hline & Strong & $1(2,5)$ & $3(5,2)$ & $34(30,2)$ \\
\hline
\end{tabular}

A chi-square analysis of this crosstable does not show a statistically significant relationship between relationship strength and customer quality expressed by means of the variable length. This implies that a strong relationship not necessarily goes with a high length of the relationship. 


\section{Hypotheses testing and answers to the research questions}

As can be concluded from tables 3 and 9, hypothesis H1 (current members of the marketing club have a relationship which is stronger than the relationship former members and potential members have with the same producer) is supported.

Although not statistically significant, from the same tables 3 and 9 it can be concluded that potential members of the marketing club have a relationship which is slightly stronger than the relationship former members have with the same producer. So, this conclusion does not support $\mathrm{H} 2$, but, in fact the reverse.

From table 9 it can be concluded that the behavioral variables differ in the same way as relationship strength, with the exception of 'length'. However, from a statistical point of view, only the significancies of the differences with respect to the monetary value are consistent with those of relationship strength.

So, in general H3 is supported, as the differences in relationship strength correspond with those of the behavioral variables, with the exception of 'length'.

Especially table 12 indicates that it is important to include behavioral as well as mental variables in a database, because both might give different implications about relationship strength and customer quality. For producers of fast moving consumer goods it might be sufficient to include behavioral data only. Table 11 shows that both behavioral and mental variables can be used to get an indication of relationship strength. By including only behavioral data in a database, it is no longer possible to analyse the strengths and weaknesses within a relationship. For that purpose it is still necessary to compare high and low quality customers with strong and weak relationships. So, for that purpose it is useful to include both kinds of variables in the database. From analyses concerning the customer-relationship matrix, it can be concluded that a database should contain behavioral as well as attitudinal data in order to measure relationship strength continously. Therefore H4 is supported. 


\section{DISCUSSION}

The strength of a relationship can be derived only partly from behavioral variables, since they only give an indication, and do not provide an estimation of areas of strengths and weaknesses. The strength of a relationship is determined by customer perceptions. For that reason attitudinal variables (trust, satisfaction, involvement, perceived switching costs and attractivity) are taken into account in this study. Other variables, that are not used in this study however, could also be:

- $\quad$ "if the customer talks positively/negatively about the company" (Liljander and Strandvik, 1994, p. 15). Loyal customers who provide free advertising and do a lot of talking over the years and drum up a lot of business can be regarded as 'referrals'/'advocates' (Reichheld and Sasser, 1990, p. 107);

"the customer complains to the personnel/service provider" (Liljander and Strandvik, 1994, p. 15);

the degree to which customers tolerate mistakes without being upset with the company (Liljander and Strandvik, 1994, p. 15).

In this study, the strength of relationships was not only measured through a relationship audit, but also by a number of behavioral indicators for that strength. However, we think that relationship strength can be measured in several more ways.

First, by measuring the perceived level of the relationship directly. Kotler (1992; 1994), for example, distinguishes five levels or relationships. Customers could be asked what type of relationship fits best to their current situation. But also, what type of relationship they do prefer for the (near) future. However, this information can be used better in addition to the information from the relationship audit. Especially the difference between current relationship level and preferred relationship level is important with respect to customers in cell number four of the customer-relationship matrix. Relationships with customers in cel number four who don't prefer an improvement in their relationship with the supplier and/or are not willing to increase their value to the company should be ended.

Another way to measure relationship strength is asking customers how much they are prepared to sacrifice (more) before switching to another supplier. How much would the producer have to raise prices before the consumer switches to another supplier? How far is the consumer prepared to drive to a store of a particular supplier before switching to another 
supplier? On the reverse, one can also ask the consumer how much he is prepared to accept a reduction, e.g. in service level, before switching to another company. How much could the provided service level be lowered without him switching to another provider? Stated in another way, what is his 'elasticity', 'acceptance level' or 'stamina'? This measures relationship strength in a more reliable way, as, according to Liljander and Strandvik (1994, p. 20), relationship strength can be defined as what it takes to break the relationship. However, this way of measuring relationship strength concentrates on the behavioral consequences of some actions taken by the supplier. No insight is provided in the attitude of the consumer towards the relationship while literature has shown that psychological elements such as satisfaction, involvement, and trust are very important in building, maintaining and improving relationships. Ultimately, we think that for measuring relationship strength, the 'organisational commitment'construct may be appropriate, as the 'degree of commitment' is synonymous to relationship strength (Storm, 1991, p. 149), and commitment is the dependent measure (Wilson 1990: 5): "If all of the preceding variables support the relationship, then there will be a high level of commitment". For that purpose the organisational commitment construct has to be adapted to the new context in which it will be used.

\section{CONCLUSION}

Relationship strength can be measured in several ways: by one indicator, a number/combination of indicators ('codes'), or by a relationship audit.

The relevance of measuring relationship strength is that it can be used to select those groups who demonstrate a higher propensity to be loyal to their supplier, product or brand, and develop an appropriate strategy for these groups, which differs from the strategy for groups that do not demonstrate that level of customer loyalty ("Customer loyalty can implicitely be seen as a synonym of strength here" (Liljander and Strandvik, 1994, p. 15)).

However, in determining the value of a customer and in developing marketing strategies, organizations look at the quality of the customer mainly (e.g. Woodside and Soni 1991). However, the value of a customer is also determined by the strength of the relationship (or the ability to develop a strong relationship) with that customer. Using the customer-relationship matrix can lead to other management implications, since this matrix not only takes into account the importance and (monetary) value of the customer, but also the quality of the 
relationship.

Since in a relationship both, a behavioral and a mental dimension can be distinguished, it is important to investigate both dimensions in order to formulate adequate (relationship) marketing strategies.

The study showed that data on aspects of the behavioral dimension give a good indication of the relationship strength (in this study monetary value seemed to be the best behavioral indicator, length the worst). However, attitudinal or mental data can give an even better indication of relationship strength, as the strength of a relationship is determined by customer perceptions. So, although relationship strength, in case of a fast moving consumer good like beer, can be measured by means of behavioral data, captured in a database, it can be concluded that to find out the strengths and weaknesses in the relationship it is important to pay attention to the attitudinal/mental dimension, since programs have to be built upon strengths and have te correct weaknesses. This is important for those marketers who are engaged in relationship marketing and direct marketing, with the aim to create a relationship with the customer. 


\section{REFERENCES}

Crosby, L.A., Evans, K.R. and Cowles, D. (1990), "Relationship Quality in Services Selling: An Interpersonal Influence Perspective", Journal of Marketing, Vol. 54, No. 3 (July), 68-81

Dwyer, F.R., Schurr, P.H. and Oh, S. (1987), "Developing Buyer-Seller Relationships", Journal of Marketing, Vol. 51, April, 11-27

Gummesson, E. (1987), Marketing - A Long Term Interactive Relationship: Contributions to a New Marketing Theory, Marketing Technique Center, Stockholm, Sweden

Hoekstra, J.C. (1993), Direct marketing, Wolters-Noordhoff, Groningen

Hoekstra, J.C. (1994), Direct marketing: van respons tot relatie, inaugural lecture at the Erasmus University in Rotterdam, Wolters-Noordhoff, Groningen

Katzenstein and Sachs (1992), Direct Marketing, 2nd. ed., MacMillan, New York.

Kotler, P. (1992), "The five levels of relationship", Marketing News, jrg. 26, p. 21

Kotler, P. (1994), Marketing Management: analysis, planning, implementation, and control, 8th. ed., Prentice-Hall, Englewood Cliffs, NJ, pp. 35-60

Liljander, V. and Strandvik, T. (1994), "The Nature of Relationship Quality", in: EIASMWorkshop on Quality Management in Services IV, Proceedings-Part II, Mame-La-Vallee, France, May 12-13, 1994

Peelen, E. (1990), "De aanbieder in het voetspoor van de consument: relatiemanagement in consumentenmarkten", Tijdschrift voor Marketing, Vol. 24, No. 5 (May), 9-17

Peelen, E. (1991), "Relaties tussen consument en aanbieder: een basis voor herhalingsaankopen", in: Bronner, A.E. (eds.), Recente ontwikkelingen in het marktonderzoek, jaarboek '91-'92 van de NVvM, de Vrieseborch, Haarlem, 168-187 
Poiesz, T.B.C. and Van Raaij, W.F. (1993), "A Psychological Approach to Relationship Quality in Industrial Markets", Papers on Economic Psychology, No. 117, Erasmus Universiteit, Rotterdam

Reichheld, F.F. and Sasser, W.E. jr. (1990), "Zero Defections: Quality Comes to Services", Harvard Business Review, September-October, pp. 105-111

Steenkamp, J.E.B.M. (1991), "Kwaliteit en 'customer relations'", Tijdschrift voor marketing, Vol. 25, No. 1 (January), 40-48

Storm, C.M. (1991), "Marketing: terug naar af?", Tijdschrift voor Marketing, Vol. 25, No. 11 (November), 144-152

Webster, F.E. jr. (1992), "The Changing Role of Marketing in the Corporation", Journal of Marketing, Vol. 56, No. 4 (October), 1-17

Wilson, D.T. (1990), Creating and Managing Buyer-Seller Relationships, ISBM Report 51990, The Pennsylvania State University

Woodside, A.G. and Soni, P.K. (1991), "Customer Portfolio Analysis for Strategy Development in Direct Marketing", Journal of Direct Marketing, Vol. 5, No. 2 (Spring), pp. 6-19 


\section{APPENDIX 1}

Table 5: $\quad$ Mean and response $(\mathrm{N})$ regarding length of the relationship

\begin{tabular}{||l|l|l|l|l||}
\hline \hline LENGTH & $\begin{array}{l}\text { current } \\
\text { members }\end{array}$ & $\begin{array}{l}\text { former } \\
\text { members }\end{array}$ & $\begin{array}{l}\text { potential } \\
\text { members }\end{array}$ & total \\
\hline current & $4.5(430)$ & $\mathrm{p}=0.2201$ & $\mathrm{p}=0.0000$ & \\
\hline former & & $4.6(97)$ & $\mathrm{p}=0.0000$ & \\
\hline potential & & & $4.0(184)$ & \\
\hline total & & & & $\begin{array}{l}4.4(711) \\
\mathrm{p}=0.0000\end{array}$ \\
\hline
\end{tabular}

Table 6: $\quad$ Mean and response $(\mathrm{N})$ regarding regularity

\begin{tabular}{||l|l|l|l|l||}
\hline $\begin{array}{l}\text { REGULA- } \\
\text { RITY }\end{array}$ & $\begin{array}{l}\text { current } \\
\text { members }\end{array}$ & $\begin{array}{l}\text { former } \\
\text { members }\end{array}$ & $\begin{array}{l}\text { potential } \\
\text { members }\end{array}$ & total \\
\hline current & $4.2(426)$ & $\mathrm{p}=0.0000$ & $\mathrm{p}=0.0772$ & \\
\hline former & & $3.3(93)$ & $\mathrm{p}=0.0013$ & \\
\hline potential & & & $3.9(183)$ & \\
\hline total & & & & $\begin{array}{l}4.0(702) \\
\mathrm{p}=0.0000\end{array}$ \\
\hline
\end{tabular}

Table 7: $\quad$ Mean and response $(\mathrm{N})$ regarding frequency

\begin{tabular}{||l|l|l|l|l||}
\hline FREQUENCY & $\begin{array}{l}\text { current } \\
\text { members }\end{array}$ & $\begin{array}{l}\text { former } \\
\text { members }\end{array}$ & $\begin{array}{l}\text { potential } \\
\text { members }\end{array}$ & total \\
\hline current & $3.7(429)$ & $\mathrm{P}=0.0002$ & $\mathrm{p}=0.7891$ & \\
\hline former & & $3.2(97)$ & $\mathrm{p}=0.0026$ & \\
\hline potential & & & $3.7(184)$ & \\
\hline total & & & & $\begin{array}{l}3.7(710) \\
\mathrm{p}=0.0007\end{array}$ \\
\hline
\end{tabular}


Table 8: $\quad$ Mean and response $(\mathrm{N})$ regarding monetary value

\begin{tabular}{|c|c|c|c|c|}
\hline $\begin{array}{l}\text { MONETARY } \\
\text { VALUE }\end{array}$ & $\begin{array}{l}\text { current } \\
\text { members }\end{array}$ & $\begin{array}{l}\text { former } \\
\text { members }\end{array}$ & $\begin{array}{l}\text { potential } \\
\text { members }\end{array}$ & total \\
\hline current & $2.0(418)$ & $\mathrm{p}=0.0415$ & $\mathrm{p}=0.0039$ & \\
\hline former & & $1.7(87)$ & $\mathrm{p}=0.9416$ & \\
\hline potential & & & $1.7(178)$ & \\
\hline total & & & & $\begin{array}{l}1.9(683) \\
\mathrm{p}=0.0052\end{array}$ \\
\hline
\end{tabular}

